\title{
Insulin Structure, Function and Diabetes Models in Animals
}

\author{
Selen Dağaşan' (1), Oytun Erbaş',2(1)
}

\begin{abstract}
INSULIN
Insulin is a peptide hormone that is synthesized and secreted by beta cells in the Langerhans islets of the pancreas. It regulates carbohydrate, fat, and protein metabolism by providing glucose in the blood to pass to fat, liver and skeletal muscle cells. A metabolic disease called diabetes occurs as a result of inadequate insulin activity in the body or the deterioration in insulin secretion in beta cells. Therefore, the discovery of insulin has been a revolutionary milestone in understanding both the treatment and prognosis of diabetes. ${ }^{[1,2]}$
\end{abstract}

\section{The discovery of insulin}

Insulin is derived from the Latin word insula, meaning island. In 1869, Paul Langerhans ${ }^{[3]}$ found an unspecified cell cluster in the pancreas other than exocrine hormones, and in the coming years, many scientists prepared pancreatic extracts to lower blood sugar and reduce glycosuria in experimental animals. However, in 1921, the pancreatic extract was not purified until the pancreatic extract applied by a group of scientists, including Canadian orthopedic doctor Frederick G. Banting and his assistant Charles Best $^{[4-6]}$ and insulin hormone was identified with this discovery. The molecular structure of insulin

'ERBAS Institute of Experimental Medicine, Illinois, USA \& Gebze, Turkey ${ }^{2}$ Department of Physiology, Medical Faculty of Demiroğlu Bilim University, Istanbul, Turkey

Correspondence: Selen Dağaşan. Deneysel Tıp Enstitüsü, 41470 GebzeKocaeli, Türkiye.

E-mail: selen_dagasan_1996@hotmail.com

Cite this article as: Dağaşan S. Insulin Structure, Function and Diabetes Models in Animals. JEB Med Sci 2020;1(3):96-101.

doi: $10.5606 /$ jebms.2020.75622

Received : October 10, 2020

Accepted : October 27, 2020

Published online : December 29, 2020

๑2020 Journal of Experimental and Basic Medical Sciences. All rights reserved.

\begin{abstract}
Insulin is a peptide hormone that is synthesized and secreted by beta cells in the Langerhans islets of the pancreas. It regulates carbohydrate, fat, and protein metabolism by providing glucose in the blood to pass to fat, liver and skeletal muscle cells. A metabolic disease called diabetes occurs as a result of inadequate insulin activity in the body or the deterioration in insulin secretion in beta cells. Diabetes may cause disability and death in the long term by causing dysfunction and damage to the eyes, kidneys, nerves, heart and blood vessels. For this reason, experimental animal models have been created in order to understand the pathogenesis of the disease, to examine and improve the disease prevention and treatment opportunities. In this review, the structure and functions of insulin, which causes diabetes in deficiency and low release, are examined in detail, and diabetic animal models are emphasized to understand the pathogenesis of the disease.

Keywords: Diabet, diabetic animal models, insulin.
\end{abstract}

was discovered in 1955 by Frederick Sanger ${ }^{[7]}$ by sequencing the amino acid sequence of pig insulin by primary sequence determination. ${ }^{[1]}$ Hexameric $2-Z n$ insulin (T structure 6), which is the 3D structure of insulin, was determined by Dorothy $C$ Hodgkin et al. in 1969 by X-ray method. ${ }^{[8]}$

\section{The structure of insulin}

Insulin has 51 amino acids and 6000 Da molecular weight in almost all species, including human. ${ }^{[9]}$ The human insulin molecule consists of two polypeptide chains, one A chain and one B chain containing 21 and 30 amino acid residues, respectively. ${ }^{[10]}$ These two chains are interconnected by SS (CysA7-CysB7 and CysA20-CysA19) with a disulfide bond, and an additional disulfide bond connects Cys A6 and CysA11 in chain $A$ (Figure 1). The amino acids of the two chains also participate in many non-covalent interactions. ${ }^{[9]}$

Although insulin binds to the insulin receptor in the form of a monomer, it turns into different 


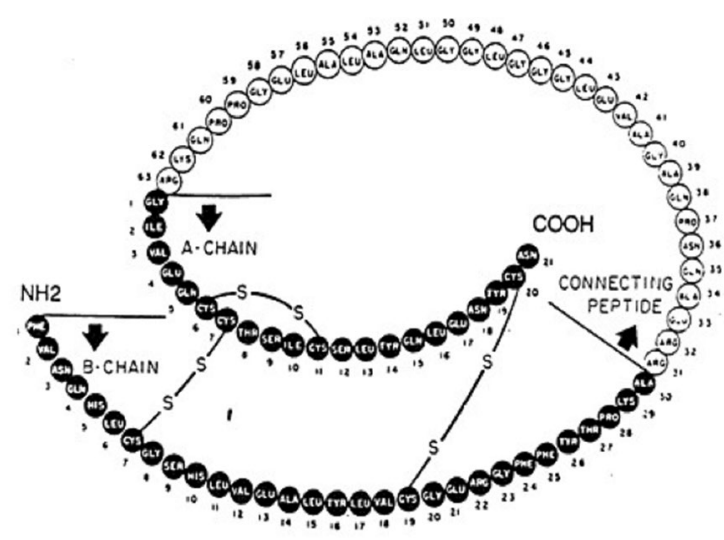

Figure 1. Primary structures of swine insulin and swine proinsulin. Human insulin is similar to swine insulin except for the exchange of $\mathrm{Ala}^{\mathrm{B} 30}$ and $\mathrm{Thr}^{\mathrm{B} 30}$.

forms in physiological or solution form. ${ }^{[1,12]}$ Formation of dimer, double dimer (tetramer), triple dimer (hexamer) or higher grade aggregates can be observed. ${ }^{[13]}$ Form of insulin in solution; It varies depending on insulin concentration, $\mathrm{pH}$, solution composition and metal ion concentration. This also affects the charge and solubility of the insulin molecule. ${ }^{[11,13]}$ Monomeric human insulin molecules in solution at physiological $\mathrm{pH}$ are only present in very low concentrations $\left(<1 \times 10^{-9} \mathrm{M}\right)$. The dimer is formed

(a)

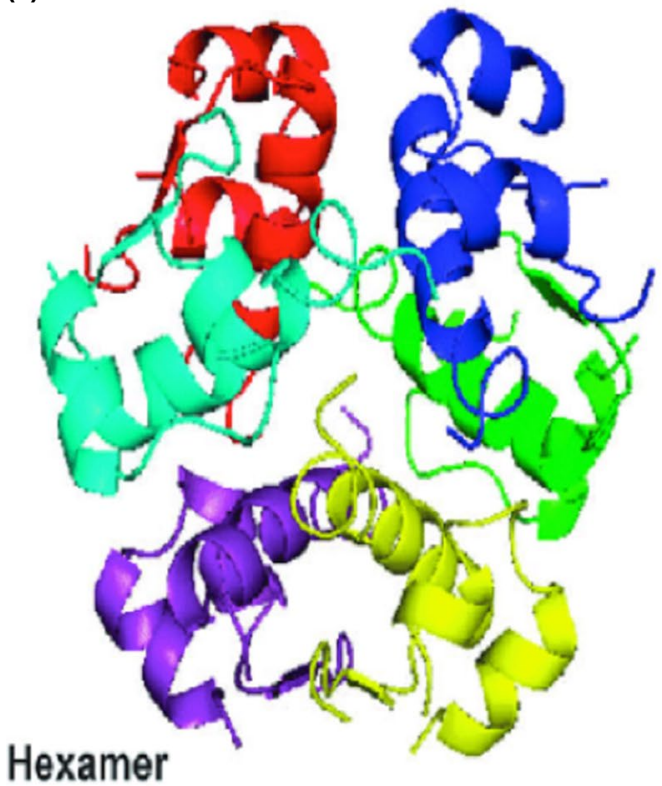

at a concentration of $1 \times 10^{-6} \mathrm{M} \cdot{ }^{[11,13]}$ In the blood, the physiological concentration of insulin is $<1 \times 10^{-9} \mathrm{M}$, and it provides its biological effect by participating in the insulin circulation in the form of a monomer. ${ }^{[11]}$ In case of increased concentration, insulin collection is initiated and several models have been proposed to identify the case in the absence of metal ions. ${ }^{[1,14]}$ In the presence of zinc or other metal ions; three human insulin dimers easily combine with hexamer. ${ }^{[13,15]} 2 \mathrm{Zn}$ hexameric insulin is collected in the coordination of two zinc ions and has a structure similar to the natural storage types of the peptide in pancreatic beta cells. ${ }^{[15]}$ This structure also prevents the formation of higher grade aggregates. The monomer form of insulin is active; The complexes formed are not active, but they can be progressively cleaved to release active proteins (Figures 2). This feature is used to create long-acting insulin medical formulations. ${ }^{[16,17]}$

Although the amino acid sequence of insulin varies among the species, the positions of the three sulfur bonds, some parts of the molecule, both ends of the A chain, and the C-terminal residues of the B chain are highly preserved. This similarity leads to a three-dimensional form of insulin, which is very similar across species, and insulin from an animal is likely to be biologically active in other species. Until the discovery of synthetic human insulin, swine and bovine insulin were used in the treatment of diabetes.

(b)

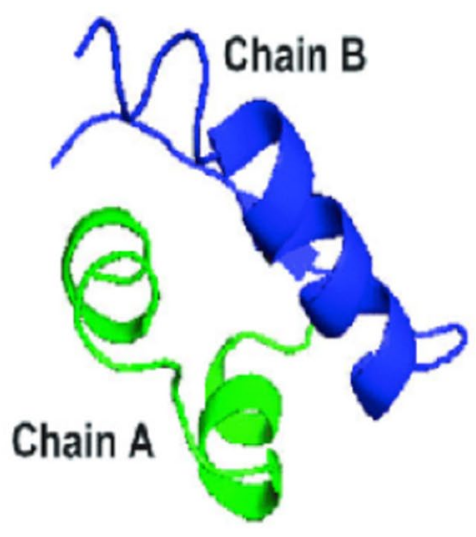

\section{Monomer}

Figure 2. (a) Insulin hexamer and (b) Insulin monomer crystal structures. ${ }^{[19]}$ Insulin monomer structure is active hormone and hexamer structure is storage form. (A) Each of the 6 monomers is shown in a different color. 
Pig insulin differs from human insulin in the $B$ chain; Threonine, the $30^{\text {th }}$ amino acid in human insulin, was replaced by alanine in pig insulin (Figures 2). Bovine insulin differs in both $A$ and $B$ chains. Threonine which is the 8th amino acid in chain $A$ of human insulin is replaced by alanine, the $10^{\text {th }}$ amino acid isoleucine by valine, and the $30^{\text {th }}$ amino acid threonine is replaced by alanine in chain B. Due to these structural differences, there is a higher risk of developing local and systemic reactions, lipodystrophy and antibody at the injection site, especially against bovine insulin. ${ }^{[18,19]}$

\section{Biosynthesis of insulin}

Insulin is the biosynthetic product of preproinsulin, a single-chain precursor due to the exchange of proteolytic processes between cellular compartments. Biosynthesis of insulin; It begins by converting insulin mRNA into preproinsulin, a single molecule of 110 amino acids. After this structure passes through the endoplasmic reticulum, the signal consisting of 24 amino acids under the enzyme effect is separated from the peptide structure and transformed into proinsulin structure by folding and binding. Then proinsulin passes into the golgi apparatus and is exposed to several specific endopeptidases that exclude the $C$ peptide (one of the three domains of proinsulin) consisting of 33 amino acids and thus produce the mature form of insulin. Insulin is secreted from the cell by exocytosis and spreads to the islet capillary blood. The C-peptide is also secreted into the blood at a 1: 1 mole ratio with insulin. Although the C-peptide did not provide a biological detection, it is used as a useful marker for insulin secretion. ${ }^{[20-22]}$

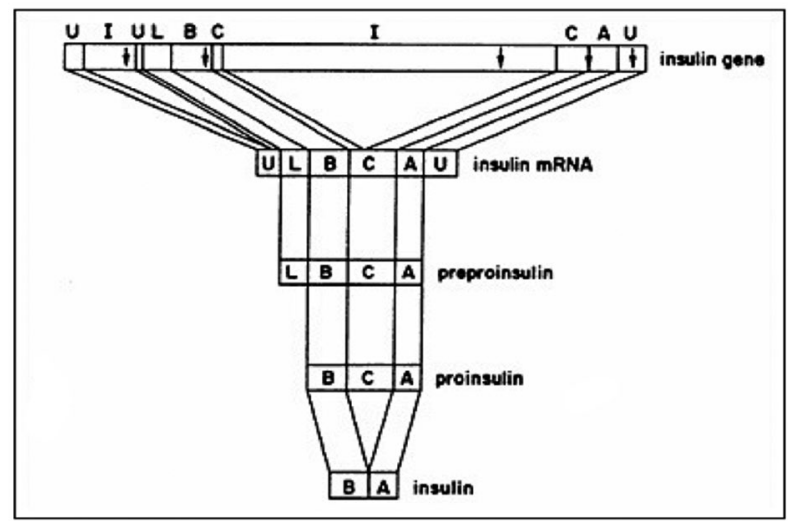

Figure 3. Schematic representation of insulin processing. Transcription and translation of the human insulin gene, as well as the processing of preproinsulin into insulin are shown. ${ }^{[12]}$

\section{Insulin receptor}

The insulin receptor is a member of the transmembrane signal proteins of the tyrosine kinase family and is synthesized as a single polypeptide. The formed polypeptide is glycosylated and divided into alpha-beta subunits, and a tetramer is formed, which is bound by disulfide bonds again. The hydrophobic part of each subunit is located within the plasma membrane. Alpha subunit contains the insulin binding site. The cytosolic part of the beta subunit is a tyrosine kinase and is activated by insulin. Binding of insulin to alpha subunits of the receptor causes positional changes (Figures 3). ${ }^{[1]}$ These changes are transmitted to beta subunits, and the tyrosine unit in these structures causes autophosphorylation. Consequently, insulin-receptor substrates (IRS-1 and IRS-2) activate phosphorylated phosphoidylinositol-3 kinase (PI3K) and mitogen activated protein kinase (MAPK) pathways. Eventually, insulin acts on the target tissues. ${ }^{[23-25]}$

\section{The function of insulin}

Insulin provides glucose homeostasis by keeping the plasma glucose value in an optimal range throughout the day. The main effects of insulin are: (i) In the liver, to stimulate glucose oxidation and storage of glucose (glycogenesis), as well as to convert glucose into triglycerides and protein synthesis, (ii) in the muscle tissue, it provides glucose uptake into the cells, and be stored as glycogen, (iii) and in fat tissue, it provides glucose uptake and conversion to triglycerides for storage. ${ }^{[22,26]}$

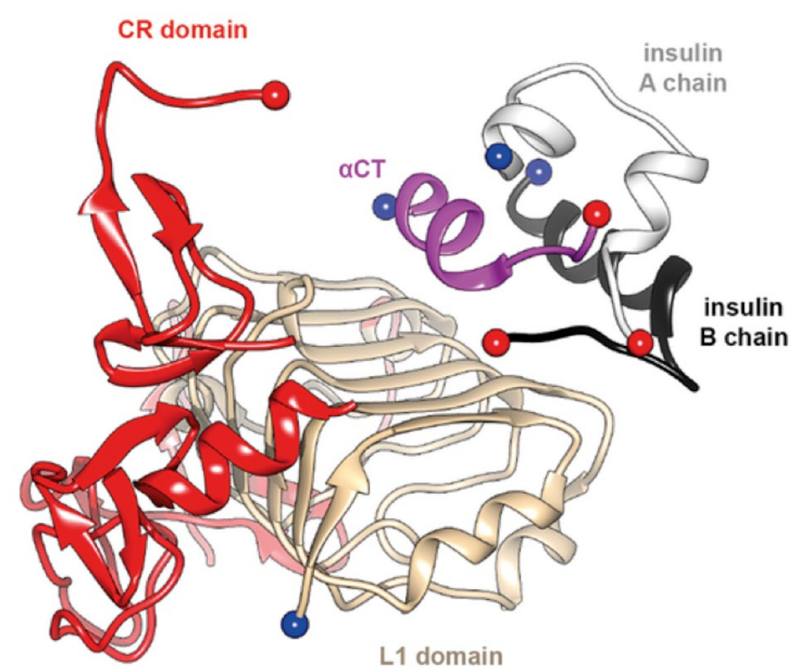

Figure 4. Interaction of insulin with the primary binding site of the receptor. ${ }^{[26]}$ Positional changes occur as a result of binding. 


\section{DIABETES MELLITUS}

Diabetes mellitus, also known as diabetes; metabolic disease characterized by insulin secretion, insulin effect, or hyperglycemia as a result of the disorder observed in both. There are two main types of diabetes: Type 1 and Type 2 diabetes. Type 1 diabetes is caused by impaired insulin secretion due to damage in $\beta$ cells, while Type 2 diabetes; It is caused by increased insulin resistance to the effect of insulin or a decrease in insulin secretion from the pancreas. $^{[27,28]}$

Diabetes may cause disability and death in the long term by causing dysfunction and damage to the eyes, kidneys, nerves, heart and blood vessels. For this reason, it is common to use experimental animal models to understand the pathogenesis of the disease and to examine the prevention and treatment opportunities. ${ }^{[27-29]}$

\section{EXPERIMENTAL ANIMAL MODELS}

In experimental animals, experimental diabetes formation can be done by using chemical agents, spontaneous or virus.

\section{1-Diabetes models created by using chemicals}

In order to trigger type 1 diabetes, the most common streptozotocin (STZ) or alloxane is used, although zinc philators (dithizone, 8-hydroxyquinoline), Rodenticide-Vacor, dietary nitrosamines are used. These compounds are similar in structure to glucose and animals are more susceptible to hypoglycemia, as glucose competes with STZ and alloxan. In addition, these substances have an unstable structure, so the formation of the solution should be done just before injection. ${ }^{[30-32]}$

STZ and alloxan are also used to create Type 2 diabetes in animals. ${ }^{[31]}$

\section{Streptozotocin (STZ)}

This structure, also called Streptozosin, is synthesized by the fungus Streptomycetes achromogenes. Its chemical structure is [2-deoxy2- (3- (methyl-3- nitrosoureido) -d-glycopyranose]. It enters beta cells with glucose in its structure with GLUT 2, causing alkylation of beta cells in DNA bases. (ADP-ribose) polymerase (PARP) discharges NAD stores and reduces ATP content using nicotinamide adenine dinucleotide (NAD) in the cell, thereby causing necrosis in beta cell. ${ }^{[31,33]}$

STZ should not leak out of the vein as it can irritate tissues. In addition, it should be used by dissolving in a citrate buffer solution with a $\mathrm{pH}$ of $4.5 .^{[31]}$
STZ can be given as a single high dose or multiple low doses. It has been observed that $100-200 \mathrm{mg} / \mathrm{kg}$ of mice given high doses at once and $35-65 \mathrm{mg} / \mathrm{kg}$ of rats cause diabetes. ${ }^{[1,34,35]}$ Multiple low doses range from 20 to $40 \mathrm{mg} / \mathrm{kg}$ per day, depending on the species and strain. Multiple low doses can be given for 5 days in rats and mice. ${ }^{[31,36,37]}$

\section{Alloxan}

Alloxan, 2,4,5,6-tetraoxypyrimidine; It has 5,6-dioxyuracil structure and its diabetic effect is due to free radical formation in beta cells. Alloxan is reduced to diraluric acid and oxidized repeatedly, and a redox cycle is formed for the formation of superoxide radicals, especially the hydrogen peroxide radical. At the end of the reaction, highly reactive hydroxyl radicals are formed which cause beta cell DNA to break down. ${ }^{[31,38]}$

Alloxane $50-200 \mathrm{mg} / \mathrm{kg}$ in mice and $40-200 \mathrm{mg} / \mathrm{kg}$ in rats is sufficient, while it can be administered intraperitoneally (i.p), subcutaneously (s.c), intravenously (i.v). ${ }^{[31,38]}$

\section{2-Spontaneous diabetes models}

Autoimmune models used in Type $1 \mathrm{DM}$; nonobese diabetic (NOD) mouse, Bio reproductive (BB) rat, LEW.1AR1 / Ztm-iddm rat. ${ }^{[39,40]}$

The NOD mouse is a lab mouse developed in Osaka in 1974. ${ }^{[41]}$ Insulitis development is observed in pancreas when it is 3-4 weeks old and diabetes develops when it is 30 weeks old. ${ }^{[42]}$ The rate of diabetes differs in genders and it is more likely to be seen in females. ${ }^{[42]}$ While the Type 1 diabetes genes in humans are parallel with NOD mice, some pathways and mechanisms are different. ${ }^{[40]}$ Therefore, there are many drugs that work in these mice but not in humans. Also, diabetes in NOD mice is negatively associated with microbial exposure, so it should be kept in specific pathogen-free conditions (SPF). ${ }^{[31]}$

Bio reproductive rats were obtained from the deceased Wistar rats and were first described in Canada in 1974. BB rats generally develop diabetes at puberty and the incidence is the same in men and women. Approximately $90 \%$ of rats develop diabetes when they are 8 to 16 weeks old. Like NOD mice, insulitis develops, whereas lymphopenia is not observed only in humans and NOD mice, while lymphopenia is observed in BB mice. This factor appears to be a disadvantage for the use of $B B$ rats as a model in Type 1 DM. ${ }^{[31,43]}$ 
LEW.1AR1/-iddm mice were raised in an MHC haplotype congeneic Lewis rat colony raised at the Hanover Medical School Laboratory Animal Science Institute. In these rats, insulitis is observed and diabetes occurs in 8-9 weeks. It is observed equally in both genders. Unlike the NOD mouse and BB rat, it does not exhibit any other autoimmune disease. ${ }^{[31,41,44]}$

Most of the type 2 diabetes animal models are obese and the classification is made accordingly. Among the monogenic obese models, Lep ob/ ob mice, Leprdb/db mice, Zucker Fatty rats (ZDF); Examples of polygenic obese models are KK mice, OLETF rats, New Zealand obese (NZO) mice, TallyHo/ Jng mice, NoncNZO10/Ltj mice. There are also nonobese animal models and Goto-Kakizaki rats, hIAPP mice are examples. ${ }^{[31]}$

In obese type 2 diabetes animal models that are obese, Lep ob/ob mice ${ }^{[45]}$ are caused by a lack of saturation-promoting leptin hormone and in Leprdb/ $\mathrm{db}$ mice, ${ }^{[46]}$ obesity is observed due to leptin hormone receptor deficiency.

Lep ob/ob mice create a severe obesity model, while weight gain begins at 2 weeks of age, and mice develop hyperinsulinemia. In addition, these mice are sterile. ${ }^{[45]}$

Leprdb/db mice originate from an autosomal recessive mutation discovered in Jackson Laboratory. When 4-8 weeks of age, hyperglycaemia is observed and ketosis develops after a few months and is shortlived. ${ }^{[31,46]}$

\section{3- Diabetes models created by virus}

Most of the encephalomyocardine virus was studied with the $M$ variant in the diabetes models created by the virus. This virus is from the picarnovirus family and as a result of injection, insulitis is observed. Stubborn hyperglycemia, ketoacidosis is observed and results in death. KRV, Coxsachie B, Rubella, Reovirus, CMV are other viruses used to create animal models of diabetes in animals. ${ }^{[4]}$

\section{Declaration of conflicting interests}

The authors declared no conflicts of interest with respect to the authorship and/or publication of this article.

\section{Funding}

The authors received no financial support for the research and/or authorship of this article.

\section{REFERENCES}

1. Vecchio I, Tornali C, Bragazzi NL, Martini M. The Discovery of Insulin: An Important Milestone in the History of Medicine. Front Endocrinol (Lausanne) 2018;9:613.
2. American Diabetes Association. Diagnosis and classification of diabetes mellitus. Diabetes care 2009;33(Suppl 1):62-9.

3. Langerhans P. Beitrage zur Mikroscopischen Anatomie der Bauchspeichel Druse. Inaugural-dissertation. Berlin: Gustav Lange; 1869.

4. Banting FG. The internal secretion of the pancreas. Am J Physiol 1922;29:479.

5. Banting FG, Best CH, Collip JB, Hepburn J, Macleod JJR, Noble EC. Preliminary studies of the physiological of insulin. Trans R Soc Can 1922;16:18.

6. Banting FC, Best $\mathrm{CH}$, Collip JB, Macleod JJR, Noble EC. The effect of pancreatic extract (insulin) on normal rabbits. Am J Phisiol 1922.

7. Sanger F. Chemistry of insulin; determination of the structure of insulin opens the way to greater understanding of life processes. Science 1959;129:1340-4.

8. Adams MJ, Blundell TL, Dodson EJ, Dodson GG, Vijayan M, Baker EN, Hardine MM, Hodgkin DC, Rimer B, Sheet S. Structure of rhombohedral 2 zinc insulin crystals. Nature 1969;224:491-5.

9. Steiner DF, Chan SJ, Welsh JM, Kwok SC. Structure and evolution of the insulin gene. Annu Rev Genet 1985;19:463-84.

10. Derewenda U, Derewenda Z, Dodson GG, Hubbard $\mathrm{RE}$, Korber F. Molecular structure of insulin: the insulin monomer and its assembly. Br Med Bull 1989;45:4-18.

11. Brange J, Owens DR, Kang S, Vølund A. Monomeric insulins and their experimental and clinical implications. Diabetes Care 1990;13:923-54.

12. De Meyts P. Insulin and its receptor: structure, function and evolution. Bioessays 2004;26:1351-62.

13. Becker $\mathrm{RH}$. Insulin glulisine complementing basal insulins: a review of structure and activity. Diabetes Technol Ther 2007;9:109-21.

14. Attri AK, Fernández $\mathrm{C}$, Minton AP. pH-dependent self-association of zinc-free insulin characterized by concentration-gradient static light scattering. Biophys Chem 2010;148:28-33.

15. Dunn MF. Zinc-ligand interactions modulate assembly and stability of the insulin hexamer -- a review. Biometals 2005;18:295-303.

16. Correia $M$, Neves-Petersen MT, Jeppesen PB, Gregersen S, Petersen SB. UV-light exposure of insulin: pharmaceutical implications upon covalent insulin dityrosine dimerization and disulphide bond photolysis. PLoS One 2012;7:e50733.

17. Tah B, Pal P, Mishra S, Talapatra GB. Interaction of insulin with anionic phospholipid (DPPG) vesicles. Phys Chem Chem Phys 2014;16:21657-63.

18. Burge MR, Schade DS. Insulins. Endocrinol Metab Clin North Am 1997;26:575-98.

19. Selam JL, Charles MA. Devices for insulin administration. Diabetes Care 1990;13:955-79.

20. Weiss M, Steiner DF, Philipson LH. Insulin Biosynthesis, Secretion, Structure, and Structure-Activity 
Relationships. 2014 Feb 1. In: Feingold KR, Anawalt B, Boyce A, Chrousos G, de Herder WW, Dungan K, editors. Endotext [Internet]. South Dartmouth (MA): MDText. com, Inc.; 2000.

21. De Meyts $P$. Insulin and its receptor: structure, function and evolution. Bioessays 2004;26:1351-62.

22. El Sayed SA, Mukherjee S. Physiology, Pancreas. [Updated 2020 Jul 10]. In: StatPearls [Internet]. Treasure Island (FL): StatPearls Publishing; 2020 Jan-. Available from: https:// www.ncbi.nlm.nih.gov/books/NBK459261/

23. Pamela CC, Richard A, Harvey JB editors. Lippincott's Illustrated Review: Biochemistry. 2nd ed. Philadelphia: Lippincott Company; 1994. p. 269-77.

24. Pedersen O, Bak JF, Andersen PH, Lund S, Moller DE, Flier JS, et al. Evidence against altered expression of GLUT1 or GLUT4 in skeletal muscle of patients with obesity or NIDDM. Diabetes 1990;39:865-70.

25. Weiss MA, Lawrence MC. A thing of beauty: Structure and function of insulin's "aromatic triplet". Diabetes Obes Metab 2018;20 Suppl 2(Suppl 2):51-63.

26. Melmed S, Conn PM, editors. Endocrinology: Basic and Clinical Principles. New Jersey: Humana Press; 2005.

27. American Diabetes Association. Diagnosis and classification of diabetes mellitus. Diabetes care 2010;33(Suppl 1):62-9.

28. Imperatore G, Mayer-Davis EJ, Orchard TJ, Zhong VW. Prevalence and incidence of type 1 diabetes among children and adults in the United States and comparison with non-U.S. countries. In: Cowie CC, Casagrande SS, Menke A, editors. Diabetes in America. 3rd ed. Bethesda, MD: National Institutes of Health; 2017. p. 2-17.

29. Pickup JC, Williams G, editors. Textbook of Diabetes. 2nd ed. Oxford: Blackwell Science Inc; 2002.

30. Bansal R, Ahmad N, Kidwai JR. Alloxan-glucose interaction: effect on incorporation of 14C-leucine into pancreatic islets of rat. Acta Diabetol Lat 1980;17:135-43.

31. King AJ. The use of animal models in diabetes research. Br J Pharmacol 2012;166:877-94.

32. Sexton WJ, Jarow JP. Effect of diabetes mellitus upon male reproductive function. Urology 1997;49:508-13.

33. Murata M, Takahashi A, Saito I, Kawanishi S. Sitespecific DNA methylation and apoptosis: induction by diabetogenic streptozotocin. Biochem Pharmacol 1999;57:881-7.
34. Srinivasan K, Ramarao P. Animal models in type 2 diabetes research: an overview. Indian J Med Res 2007;125:451-72.

35. Hayashi K, Kojima R, Ito M. Strain differences in the diabetogenic activity of streptozotocin in mice. Biol Pharm Bull 2006;29:1110-9.

36. Lukić ML, Stosić-Grujicić S, Shahin A. Effector mechanisms in low-dose streptozotocin-induced diabetes. Dev Immunol 1998;6:119-28.

37. Like AA, Rossini AA. Streptozotocin-induced pancreatic insulitis: new model of diabetes mellitus. Science 1976;193:415-7.

38. Szkudelski T. The mechanism of alloxan and streptozotocin action in B cells of the rat pancreas. Physiol Res 2001;50:537-46.

39. Yang Y, Santamaria P. Lessons on autoimmune diabetes from animal models. Clin Sci (Lond) 2006;110:627-39.

40. Lenzen $S$, Tiedge $M$, Elsner $M$, Lortz $S$, Weiss $H$, Jörns $A$, et al. The LEW.1AR1/Ztm-iddm rat: a new model of spontaneous insulin-dependent diabetes mellitus. Diabetologia 2001;44:1189-96.

41. Hanafusa T, Miyagawa J, Nakajima H, Tomita K, Kuwajima $M$, Matsuzawa Y, et al. The NOD mouse. Diabetes Res Clin Pract 1994;24 Suppl:S307-11.

42. Yoon JW, Jun HS. Cellular and molecular pathogenic mechanisms of insulin-dependent diabetes mellitus. Ann N Y Acad Sci 2001;928:200-11.

43. Mordes JP, Bortell R, Blankenhorn EP, Rossini AA, Greiner DL. Rat models of type 1 diabetes: genetics, environment, and autoimmunity. ILAR J 2004;45:278-91.

44. Jörns $A$, Günther $A$, Hedrich $H J$, Wedekind D, Tiedge $M$, Lenzen $\mathrm{S}$. Immune cell infiltration, cytokine expression, and beta-cell apoptosis during the development of type 1 diabetes in the spontaneously diabetic LEW.1AR1/Ztmiddm rat. Diabetes 2005;54:2041-52.

45. Zhang $Y$, Proenca $R$, Maffei M, Barone $M$, Leopold $L$, Friedman JM. Positional cloning of the mouse obese gene and its human homologue. Nature 1994;372:425-32.

46. Hummel KP, Dickie MM, Coleman DL. Diabetes, a new mutation in the mouse. Science 1966;153:1127-8.

47. Jun HS, Yoon JW. The role of viruses in type I diabetes: two distinct cellular and molecular pathogenic mechanisms of virus-induced diabetes in animals. Diabetologia 2001;44:271-85. 